\title{
First Records of the North American Green Treefrog (Hyla cinerea) on New Providence, The Bahamas
}

\author{
Scott Johnson and Shannan S. Yates
}

Bahamas National Trust, East Bay Street, P.O.Box N-4105, Nassau, Bahamas (sjohnson@bnt.bs)

$\mathrm{O}$ 23 April 2015, while conducting a field trip at Bonefish Pond National Park on New Providence,

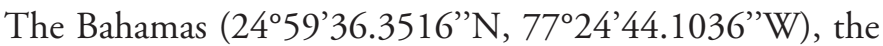
authors found the remains of an unfamiliar anuran (Fig. 1A). Unable to identify the species, photographs were sent to Mrs. Sandra Buckner and Dr. Chris Pellecchia, who confirmed the species to be a North American Green Treefrog, Hyla cinerea (Schneider 1799). Additional individuals were seen on 24 August 2018 by the second author at the Airport

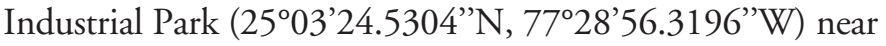
the Lynden Pindling International Airport (Fig. 1B) and on 13 June 2019 by Royal Bahamas Defense Force Marine Seaman Lyndon Rolle along Cowpen Road near Bonefish Pond National Park (Fig. 1C). An additional observation by Sandra Buckner in the Lyford Cay area was communicated informally. Photographic vouchers have been deposited in the Milwaukee Public Museum (MPM VZP 939-941).

The North American Green Treefrog, which was recently assigned to the genus Dryophytes (as Dryophytes cinereus) by Duellman et al. (2016), is native to the southeastern United States (e.g., Redmer and Brandon 2003). Introduced popula- tions have been recorded in Puerto Rico (Redmer et al. 1999; Redmer and Brandon 2003) and in Big Bend National Park, Texas (Leavitt et al. 2007).

The importation of decorative plants and other products into The Bahamas from North America has resulted in the arrival of several species of non-native amphibians. These include the Pig Frog (Lithobates grylio), Squirrel Treefrog (Hyla squirella), Southern Leopard Frog (Lithobates sphenocephalus), Eastern Narrow-mouthed Frog (Gastrophryne carolinensis), and the invasive Cane Toad (Rhinella marina) (Crombie 1972; Powell et al. 2011; Knapp et al. 2011; Giery et al. 2017; Johnson and Gibson 2018). The North American Green Treefrogs probably were introduced in containers of decorative plants.

The presence of non-native/invasive amphibian species into The Bahamas can endanger native anurans by exposing them to the deadly chytrid fungus (e.g., Powell et al. 2011). Consequently, more stringent inspections of plants and other products coming into the country needs to be incorporated into the export and importation regulations in order to protect the native herpetofauna.
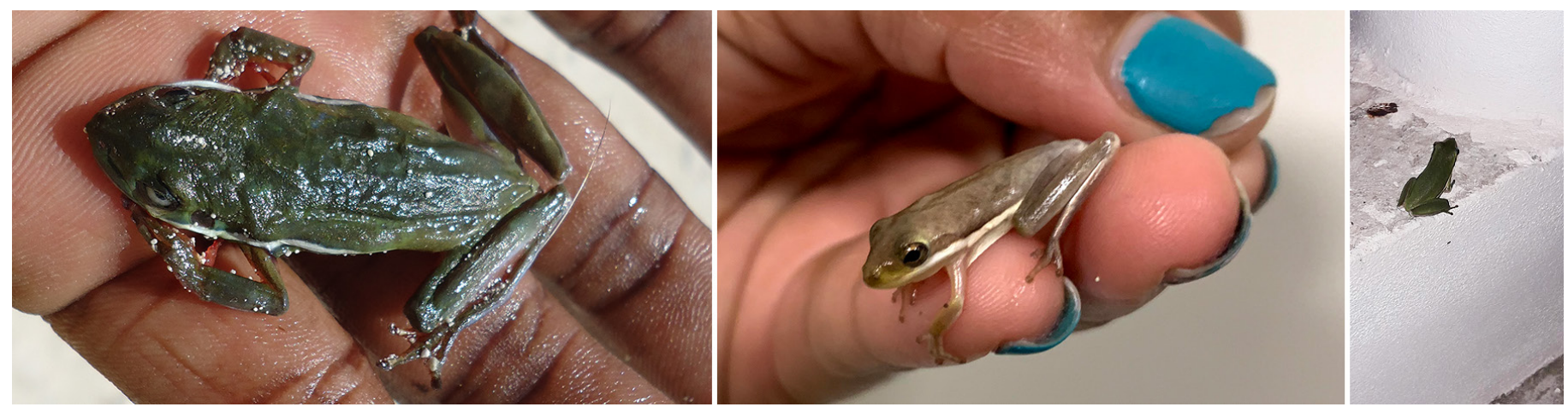

Fig. 1. (A) Deceased North American Green Treefrog (Hyla cinerea) found on 23 April 2015 at Bonefish Pond National Park, New Providence, The Bahamas. Photograph by Scott Johnson. (B) North American Green Treefrog (Hyla cinerea) found at the Airport Industrial Park, New Providence, The Bahamas, on 24 August 2018. Photograph by Shannan Yates. (C) North American Green Treefrog (Hyla cinerea) found along Cowpen Road near Bonefish Pond National Park, New Providence, The Bahamas, on 13 June 2019. Photograph by Lyndon Rolle. 


\section{Acknowledgements}

We thank Sandra Buckner and Dr. Chris Pellecchia for identifying these frogs.

\section{Literature Cited}

Crombie, R.I. 1972. The presence of Hyla squirella in the Bahamas. Quarterly Journal of the Florida Academy of Sciences 35: 49-52.

Duellman, W.E., A.B. Marion, and S.B. Hedges. 2016. Phylogenetics, classification, and biogeography of the treefrogs (Amphibia: Anura: Arboranae). Zootaxa 4104: 1-109.

Giery, S.T., D. Richard, and J.T. Stroud. 2017. Establishment of the Eastern Narrowmouthed Frog (Gastrophryne carolinensis) on Abaco Island in The Bahamas, with notes on the species' current distribution in the West Indies. Reptiles \& Amphibians 24: 139-141.

Johnson, S. and D. Gibson. 2018. South American Cane Toad (Rhinella marina) found on Great Guana Cay, Abaco, The Bahamas. Reptiles \& Amphibians 25: $160-161$.
Knapp, C.R., J.B. Iverson, S.D. Buckner, and S.V. Cant. 2011. Conservation of amphibians and reptiles in the Bahamas, pp. 53-87. In: A. Hailey, B.S. Wilson, and J.A. Horrocks (eds.), Conservation of Caribbean Island Herpetofaunas. Volume 2: Regional Accounts of the West Indies. Brill, Leiden, The Netherlands.

Powell, R., R.W. Henderson, M.C. Farmer, M. Breuil, A.C. Echternacht, G. van Buurt, C.M. Romagosa, and G. Perry. 2011. Introduced amphibians and reptiles in the Greater Caribbean: patterns and conservation implications, pp. 63-143. In: A. Hailey, B.S. Wilson, and J.A. Horrocks (eds.), Conservation of Caribbean Island Herpetofaunas. Volume 1: Conservation Biology and the Wider Caribbean. Brill, Leiden, The Netherlands.

Redmer, M. and R.A. Brandon. 2003. Hyla cinerea. Catalogue of American Amphibians and Reptiles 766: 1-14.

Redmer, M., L.E. Brown, and R.A. Brandon. 1999. Natural history of the BirdVoiced Treefrog (Hyla avivoca) and Green Treefrog (Hyla cinerea) in southern Illinois. Illinois Natural History Survey Bulletin 36: 37-66.

Leavitt, D.J., T.C. Mullet, C.M. Ritzi, and J.R. Skiles. 2007. Geographic distribution. Hyla cinerea (Green Treefrog). Herpetological Review 38: 97. 